\title{
https://doi.org/10.46813/2021-134-049 \\ FOCUSING OF POSITRON BUNCH WHEN MOVING IN ELECTRON BUNCH WAKEFIELD IN THE DIELECTRIC WAVEGUIDE FILLED WITH PLASMA
}

\author{
G.V. Sotnikov, R.R. Knyazev, P.I. Markov, I.N. Onishchenko \\ National Science Center “Kharkov Institute of Physics and Technology”, Kharkiv, Ukraine \\ E-mail: sotnikov@kipt.kharkov.ua
}

The results of numerical PIC-simulation of focusing accelerated (test) positron and drive electron bunches in the dielectric waveguide filled with radially heterogeneous plasma with the vacuum channel are given in the paper. The wakefield was excited by electron bunch in quartz dielectric tube, inserted into cylindrical metal waveguide. The internal area of dielectric tube has been filled with plasma different transverse density profiles, heterogeneous on radius, with the vacuum channel along waveguide axis. Plasma density for all studied cases was so low that plasma frequency was less, than the frequency of the main dielectric mode. Results of numerical PIC simulation have shown that possibility of simultaneous acceleration and focusing of the test positron bunch are possible in the wakefield. The best acceleration happens in case of plasma absence, however at that there is no focusing of test positron bunch.

PACS: 41.75.Ht, 41.75.Lx, 41.75.Jv, 96.50.Pw

\section{INTRODUCTION}

The dielectric wakefield accelerator (DWA) is the promising applicant at construction electron - positron collider in teraelectronvolt power range [1 - 5].

Despite the possibilities of obtaining high rates of wakefield acceleration shown theoretically and experimentally, one problem which is not solved completely remains. It consists in insufficient stabilization of the transverse motion of the drive and accelerated bunches and, thus, in receiving the accelerated particles bunches with small emittance. This DWA defect can lead to destruction of bunch instability (BBU) [6].

For suppression of this instability it was offered to fill the DWA drift channel with plasma of certain density [7, 11] (PDWA). The reason of improvement of transverse stability consists in excitation in the drift channel of the plasma wave possessing the focusing properties. In these works the PDWA research has been executed for the homogeneous radial density of the plasma created by external source.

Other, widely applicable way of plasma creation is the capillary discharge. In this case heterogeneous distribution of plasma density $[12,13]$ (the BPM model) forms for a long time.

For improvement of transportation of the drive and accelerated bunches the vacuum channel in plasma that reduces bunches scattering and deviation (PWFA research) can be used. In the work [14] by means of PICsimulation the effect of influence of the vacuum channel in radially heterogeneous plasma for the drive and accelerated electron bunches focusing in PDWA has been studied.

In the present work positron bunch acceleration by drive electron bunch in PDWA and its focusing in radially heterogeneous plasma with the vacuum channel is investigated.

\section{PROBLEM DEFINITION}

In our researches the dielectric tube with inner radius $a$ and outer $b$, inserted into cylindrical metal waveguide was used. The internal area of dielectric tube between radiuses $r_{p 1}$ and $a$ was also filled by plasma. Thus, there was vacuum tube of radius $r_{p 1}$ around the system axes.

The drive electron bunch of cylindrical form with radius $r_{b}$ passed through the slowing-down structure along its axis and excited wakefield. Through certain delay time $t_{d e l}$ after the drive bunch the positron bunch with absolute value of charge by 60 times smaller, than at the drive was injected in system along its axis. We supposed that the initial sizes of electron and positron bunches was identical. Structure with the drive electron and witness positron bunch we call the plasma dielectric wakefield accelerator of positrons (PDWAP). The schematic type of PDWAP is shown in Fig. 1.

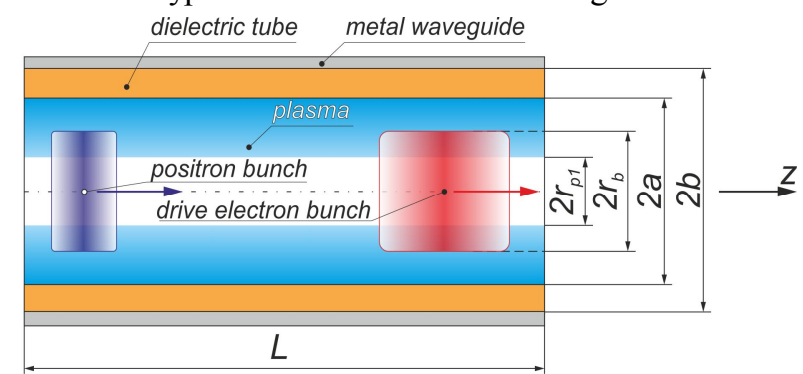

Fig. 1. Schematic type of longitudinal section of the PDWAP. The pink cylinder shows the drive electron bunch, the violet cylinder shows the positron bunch. With blue color the area filled with plasma, and orange the dielectric tube are depicted

The parameters of the waveguide, drive and the witness (test) bunches, used in calculations are specified in Table.

The parameters used in calculations

\begin{tabular}{|l|l|}
\hline Inner radius of dielectric tube, $a$ & $0.5 \mathrm{~mm}$ \\
\hline Outer radius of dielectric tube, $b$ & $0.6 \mathrm{~mm}$ \\
\hline Inner radius of the plasma cylinder, $r_{p l}$ & $0 \ldots 0.5 \mathrm{~mm}$ \\
\hline Waveguide length, $L$ & $8 \mathrm{~mm}$ \\
\hline
\end{tabular}




\begin{tabular}{|l|l|}
\hline Dielectric permittivity, $\varepsilon$ & 3.75 (quartz) \\
\hline Energy of bunches, $E_{0}$ & $5 \mathrm{GeV}$ \\
\hline Drive electron bunch charge & $-3 \mathrm{nC}$ \\
\hline Witness (test) positron bunch charge & $0.05 \mathrm{nC}$ \\
\hline $\begin{array}{l}\text { Size of longitudinal root-mean-square } \\
\text { deviation of drive bunch charge, } 2 \sigma \\
\text { (Gaussian charge distribution) }\end{array}$ & $0.1 \mathrm{~mm}$ \\
\hline $\begin{array}{l}\text { The full length of drive bunch used at } \\
\text { PIC-simulation }\end{array}$ & $0.2 \mathrm{~mm}$ \\
\hline $\begin{array}{l}\text { Size of longitudinal root-mean-square } \\
\text { deviation of witness (test) bunch charge }\end{array}$ & $0.05 \mathrm{~mm}$ \\
\hline The full length of witness bunch & $0.1 \mathrm{~mm}$ \\
\hline Bunch diameter, $2 r_{b}$ & $0.9 \mathrm{~mm}$ \\
\hline Paraxial plasma density at $r_{p l}=0$ & $4.41 \cdot 10^{14} \mathrm{~cm}^{-3}$ \\
\hline
\end{tabular}

When simulation capillary discharge three different models of plasma density dependence on radius were used $\left.n_{p}(r): 1\right)$ homogeneous, 2) parabolic with square dependence on radius, and 3) the dependence received numerically by N.A. Bobrova, etc. [12]. On vacuumplasma border at $r=r_{p 1}$ stepped behavior $n_{p}(r)$ as functions of radius $r$ was supposed (Fig. 2).
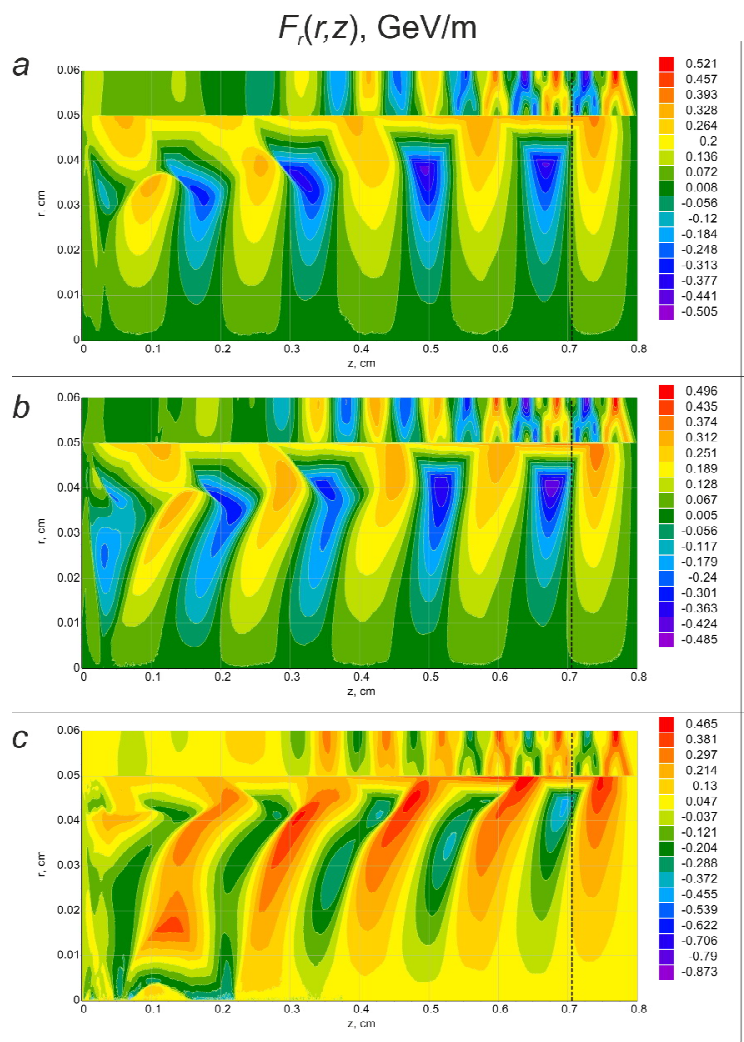

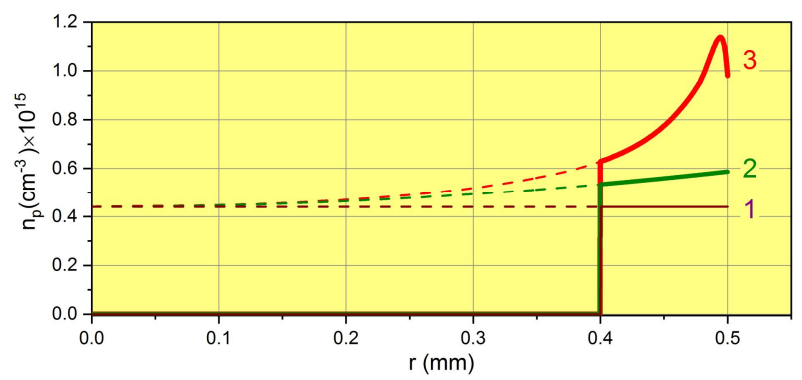

Fig. 2. Plasma density dependence on radius $r$ models for two cases: the plasma cylinder which is completely filling the internal area of dielectric tube (dotted line) and the plasma cylinder with inner radius $r_{p 1}=0.4 \mathrm{~mm}$

(continuous curve)

\section{RESULTS OF 2.5-DIMENSIONAL PIC-SIMULATION}

At numerical simulation by means of the 2.5D PIC code created by us we studied wakefield topography and dynamics of electron and positron bunches at their motion in the drift chamber. For each model of plasma density dependence on radius we investigated multiple choices with the different initial inner plasma cylinder radius $r_{p 1}$ changing in the range from 0 to $0.5 \mathrm{~mm}$.
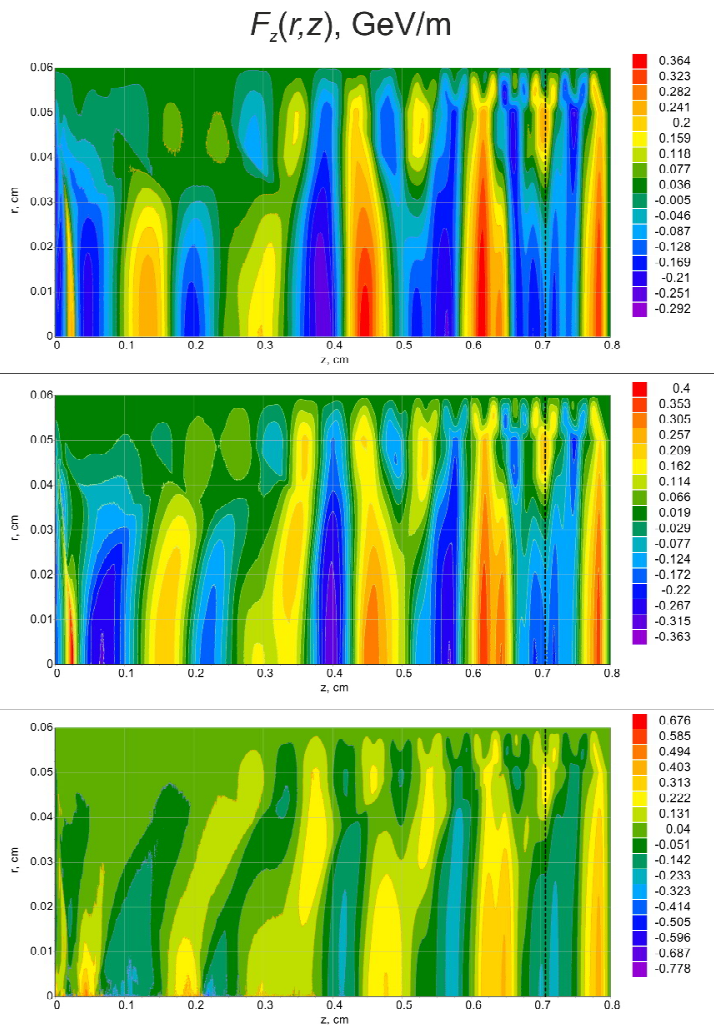

Fig. 3. Color maps and level lines for transverse $F_{r}(r, z)$ (at the left) and longitudinal $F_{z}(r, z)$ (on the right) component of Lorentz force, acting on test positron for the time $t=26.69 \mathrm{ps}$ at different plasma density dependences on radius: $a$-homogeneous; $b$-parabolic; $c$-the dependence received by N.A. Bobrova for case $r_{p 1}=0$

In Fig. 3 comparative snapshots of the Lorentz force components operating on test positron in PDWAP for $t=26.69 \mathrm{ps}$ at different plasma density dependences on radius are shown: a) homogeneous; b) parabolic; c) the dependence received by N.A. Bobrova for case $r_{p 1}=0$ (that is, for continuous filling the drift channel with plasma). The dotted line has shown the test bunch position.

For the explanation of the focusing mechanism of the accelerated positron bunch in Fig. 4 the phase space combined with dependences of longitudinal $F_{z}(z)$ and transverse forces $F_{r}(z)$ at $r=0.45 \mathrm{~mm}$ for the same 
time as in Fig. 3 for $r_{p 1}=0$ are shown. By the red color near output end face on phase space of Fig. 4 energy of drive electron bunch is shown. By blue color energy of the accelerated positron bunch is shown. The delay of test bunch is chosen so that it provided as its acceleration in local minimum of longitudinal force $F_{z}$, and transverse focusing in local maximum of transverse force $F_{r}$.

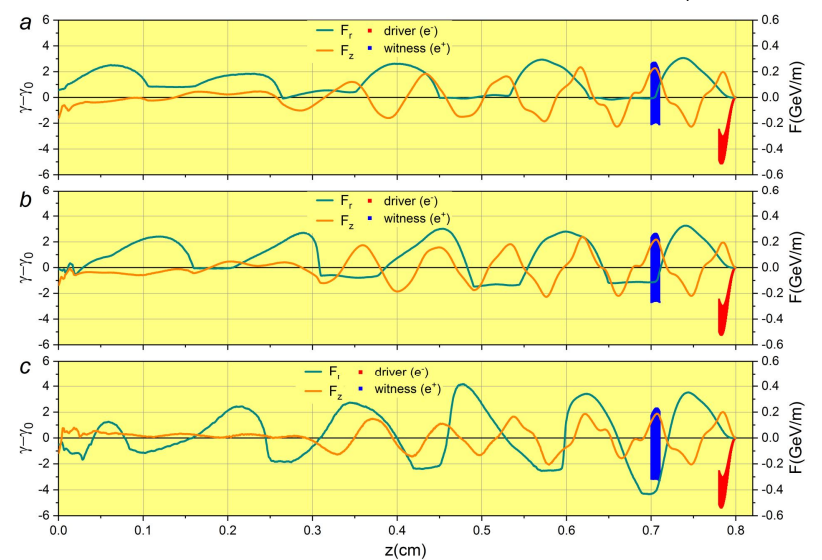

Fig. 4. Phase space energy-longitudinal coordinate, combined with dependences of longitudinal $F_{z}(z)$ and transverse forces $F_{r}(z)$ at $r=0.45 \mathrm{~mm}$ for the same

time, as in Fig. 3 for $r_{p 1}=0$ and different plasma

density dependences on radius: a - homogeneous;

$b$ - parabolic; $c$ - the dependence received

by N.A. Bobrova. By blue color energy

of the accelerated positron bunch, by red color energy of drive electron bunch are shown

As appears from Fig. 4, amplitude $(0.2 \mathrm{GeV} / \mathrm{m})$ and frequency $(372.2 \mathrm{GHz})$ which are characteristics of longitudinal (accelerating) wakefield component, poorly depend on what model of plasma density dependence on radius is used in calculations. Therefore for ensuring acceleration of test bunch the identical delay of test bunch regardless of the studied plasma density model can be chosen. At the same time transverse (focusing) wakefield component considerably changes the amplitude and frequency characteristics. For model (3), amplitude of transverse field is approximately twice more, and the frequency 1.4 times higher, than at homogeneous distribution (1). It has to be taken into account when developing the plasma and dielectric wakefield accelerator with two bunches [2 - 5]. Nevertheless, taking into account the dependences of transverse force $F_{r}$ shown on Figs. 3 and 4, the beginning of the first transverse minimum at the left $F_{r}$ has the same longitudinal coordinate $z$, as local $F_{z}$ maximum. Therefore for the 2nd and 3rd plasma density dependences on radius it is possible to expect both acceleration, and simultaneous focusing of positron bunch. For the plasma density, homogeneous on radius (case 1) we will not receive focusing of positron bunch in this research.

For illustration of influence of paraxial vacuum tube radius $r_{p 1}$ on focusing and acceleration of test bunch in Fig. 5 has shown the phase space combined with dependences of longitudinal $F_{z}(z)$ and transverse forces $F_{r}(z)$ at $r=0.45 \mathrm{~mm}$ for the same time as in Fig. 3 at different $r_{p 1}$ values: a) $r_{p 1}=0.5 \mathrm{~mm}$, b) $r_{p 1}=0.4 \mathrm{~mm}$, c) $r_{p 1}=0.2 \mathrm{~mm}$, d) $r_{p 1}=0$ for the plasma density dependence on radius received by N.A. Bobrova. Let's notice that case a) corresponds to plasma absence in the drift channel, and case d) corresponds to its full filling with plasma. By blue color energy of the accelerated positron bunch, by red color energy of drive electron bunch are shown.

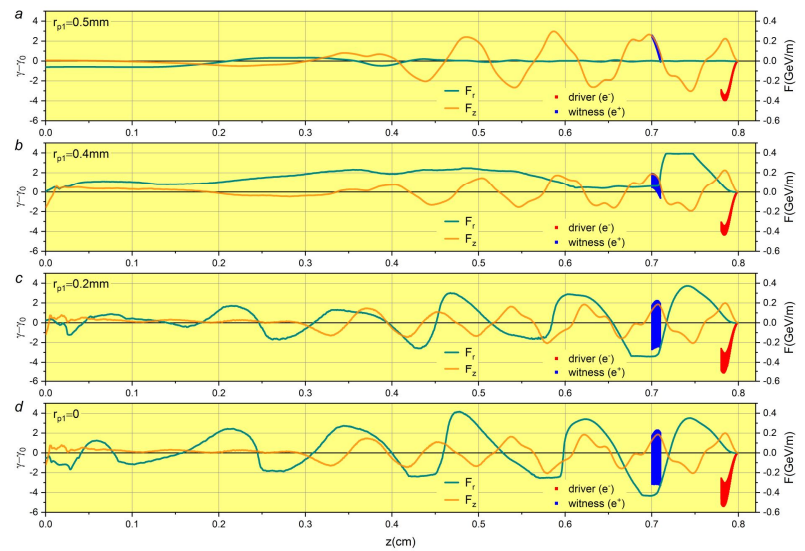

Fig. 5. Phase space energy-longitudinal coordinate, combined with dependences of longitudinal $F_{z}(z)$

and transverse forces $F_{r}(z)$ at $r=0.45 \mathrm{~mm}$ for time $t=26.69 \mathrm{ps}$ at different $r_{p 1}$ values: $a-r_{p 1}=0.5 \mathrm{~mm}$;

$$
b-r_{p 1}=0.4 \mathrm{~mm} ; c-r_{p 1}=0.2 \mathrm{~mm} ; d-r_{p 1}=0
$$

for the plasma density dependence on radius received

by N.A. Bobrova. By blue color energy of positrons

of the accelerated bunch, red-energy of electrons of drive bunch are shown

As appears from the chart depicted on Fig. 5,a in the plasma absence in the drift channel transverse force $F_{r}$ does not arise. Thereof there is no focusing of test bunch also. In case $r_{p 1}=0.4 \mathrm{~mm}$ thickness of the plasma cylinder is $0.1 \mathrm{~mm}$ and positron bunch only slightly (on $0.05 \mathrm{~mm}$ ) touch plasma. As appears from Fig. 5,b, in this case the transverse force $F_{r}$ for focusing positrons is also absent.

At further $r_{p 1}$ increase thickness of the plasma cylinder also increases and bunch positrons get into plasma more and more. In Fig. 5,c,d cases $r_{p 1}=0.2 \mathrm{~mm}$ and $r_{p 1}=0$ are shown respectively. It is possible to see that at the same time transverse force $F_{r}$ is excited also. Its maximum located in that place where there is test positron bunch is: 0.34 and $0.42 \mathrm{GeV} / \mathrm{m}$, respectively. Focusing of bunch is consequence of it. The best focusing of positron bunch is observed at full drift channel filling with plasma.

The behavior of radiuses $R_{\max }$ of bunches at change of smaller plasma tube $r_{p 1}$ radius from 0 to $0.5 \mathrm{~mm}$ for time $t=26.69 \mathrm{ps}$ is shown in Fig. 6 above. As appears from the curves shown in Fig. 6 at $r_{p 1}$ increase from 0 to $0.4125 \mathrm{~mm}$ for the plasma density dependence on radius received by N.A. Bobrova and to $0.4 \mathrm{~mm}$ for homogeneous and parabolic dependences gradual deg- 
radation of test positron bunch focusing is observed, at further $r_{p 1}$ increase focusing improves a little. When bunches moves in the vacuum channel, i.e. when the plasma tube is outside of bunches, focusing is absent.

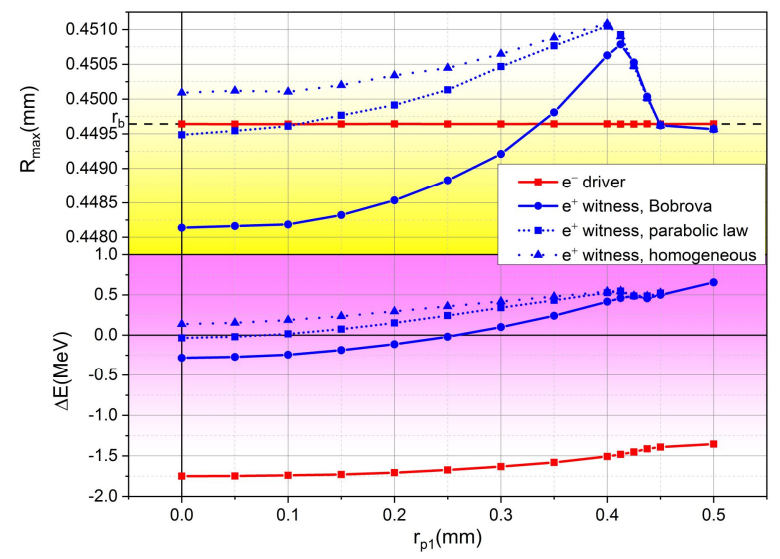

Fig. 6. Behavior of radiuses $R_{\max }$ of bunches (above) and energy change of the accelerated test positron bunch and the slowed-down drive electron bunch at change of smaller plasma tube radius $r_{p 1}$ for time $t=26.69 \mathrm{ps}$ for different plasma density dependences on radius

As appears from Fig. 6, focusing of drive electron bunch is absent (the black dotted line in Fig. 6 has shown the radius of bunches $r_{b}$ used in calculations). It is according to curves of transverse force $F_{r}$, shown in Figs. 4 and 5: in the "head" of drive bunch transverse force is absent while in the "tail" of this bunch transverse force has a negative value and focusing bunch electrons. Therefore the greatest radius of drive bunch after passing of the drift chamber does not change.

For explanation of bunches radiuses behavior given on Fig. 6, we will analyze plasma electrons behavior in the drift channel. In Fig. 7 dependences of plasma electron concentration $n_{p e}(r, z)$ for time $t=5.9 \mathrm{ps}$ at full filling with plasma of drift channel, $r_{p 1}=0.45 \mathrm{~mm}$ (a), at $r_{p 1}=0.4 \mathrm{~mm}$ (b) and at $r_{p 1}=0$ (c) are shown. Red and blue rectangles in Fig. 7 show the position of drive and test bunches.

As appears from the plots shown on Fig. 7, drive electrons try to push out plasma electrons on the periphery of drift channel area. Therefore behind the driver plasma ions surplus is formed. These ions attract the plasma electrons which are pushed out by the driver, and they rush to structure axis. Thus it should be noted that plasma ion concentration for delay time of test bunch $t_{d e l}$ practically does not change.

In case of full filling drift channel with plasma, at $r_{p 1}=0$ (see Fig. 7,c) the processes noted above lead to formation of area with the increased plasma electrons concentration at $r \leq r_{b}$. Plasma electrons excess near the upper bound of test bunch directs the positrons which are on the periphery to axis of structure and, thus focuses bunch.

At increase $r_{p 1}$ excess concentration of plasma electrons at $r \leq r_{b}$ where is test bunch, decreases. As a result at $r_{p 1}=0.4 \mathrm{~mm}$ (see Fig. 7,b) in that place where there are peripheral positrons of test bunch, plasma electrons are, practically, absent. On the other hand, the plasma ionic background leads to test bunch positrons defocusing.
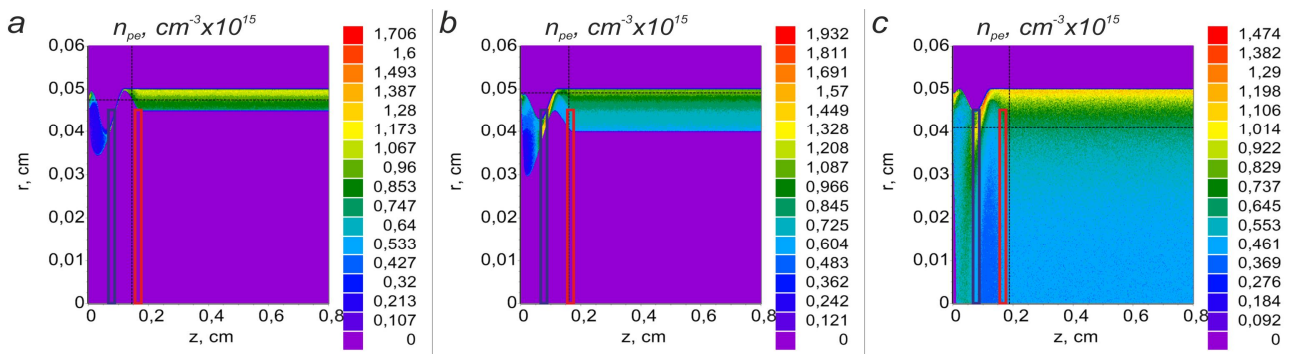

Fig. 7. Dependences of plasma electron concentration $n_{p e}(r, z)$ for time $t=5.9 \mathrm{ps}$ at $r_{p 1}=0.45 \mathrm{~mm}(\mathrm{a})$, $r_{p 1}=0.4 \mathrm{~mm}$ (b) and $r_{p 1}=0$ (c) for the plasma density dependence on radius received by N.A. Bobrova.

\section{Red and blue rectangles show the position of drive and test bunches}

Therefore at increase $r_{p 1}$ from 0 to $0.336 \mathrm{~mm}$ (for the plasma density dependence on radius received by N.A. Bobrova) deterioration of test bunch focusing is observed (see Fig. 6). At further increase $r_{p 1}$ from 0.336 to $0.4125 \mathrm{~mm}$ there is test bunch defocusing. At increase $r_{p 1}$ from 0.4125 to $0.45 \mathrm{~mm}$ growth of test bunch defocusing is replaced by its reduction. This results from the fact that plasma ions defocus the positrons of test bunch which are only on radiuses from $r_{p 1}$ to $r_{b}$ i.e. with $r_{p 1}$ growth the quantity of such ions decreases that, in turn, reduces the defocusing effect which had by them.
If the test bunch moves in the vacuum channel i.e. when the plasma tube surrounds bunches (see Fig. 7,a), surplus of plasma ions in comparison with plasma electrons is observed out of test bunch and it does not render what influence on its focusing.

The numerical experiments carried out by us have allowed to estimate also influence of the plasma tube sizes on energy change of the test and drive bunches for different plasma density dependences on radius. In Fig. 5 it is possible to notice that for plasma density dependence on radius received by N.A. Bobrova for plasma absence at $r_{p 1}=0$ (see Fig. 5,a) the test bunch is accelerated more strongly, than in the plasma presence in the drift channel (see Fig. 5,b, c and d). 

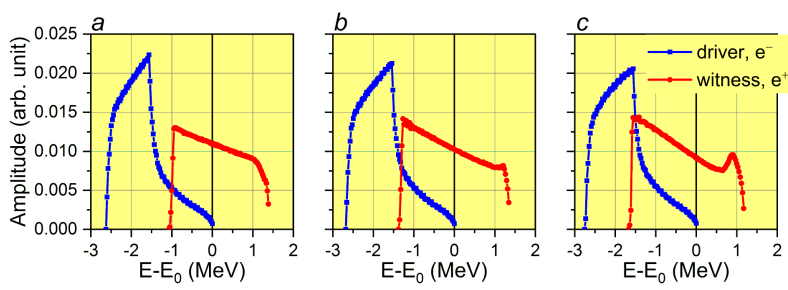

Fig. 8. Distribution functions of drive bunch electrons and test bunch positrons on energy for different plasma density dependences on radius: $a$ - homogeneous; $b-$ parabolic; $c$-the dependence received by N.A. Bobrova. $E_{0}=5 \mathrm{GeV}$. By blue color distribution function of test bunch positrons, red -drive bunch electrons is shown

The patterns noted above are clearly demonstrated by Fig. 7 (below) on which dependencies of energy change of the test bunch (blue curve) and the sloweddown drive bunch (red curve) are shown at change of smaller radius of plasma tube $r_{p 1}$ from 0 to $0.5 \mathrm{~mm}$ for time $t=26.69 \mathrm{ps}$ for different plasma density depend-
More detailed information on energy transmission from the drive bunch to test one is given by Fig. 8 in which distribution functions of drive electrons and test bunch positrons on energy for time $t=26.69 \mathrm{ps}$ for different plasma density dependences on radius are presented at $r_{p 1}=0$ (that is, for continuous filling of the drift channel with plasma). It is possible to see that though we injected monoenergetic bunches, final distribution was rather wide. Thus drive bunch distribution closely to Gaussian, and test bunch - to trapezoid.

Distribution functions of drive electron and test positron bunches on energy are given in Fig. 9 for homogeneous, parabolic and the plasma density dependence on radius received by N.A. Bobrova for time $t=26.69 \mathrm{ps}$ at different $r_{p 1}$ values. As appears from plots, at $r_{p 1}$ increase drive and test bunches distribution width decreases, and distribution of test bunch comes nearer to the Gaussian.

ences on radius.
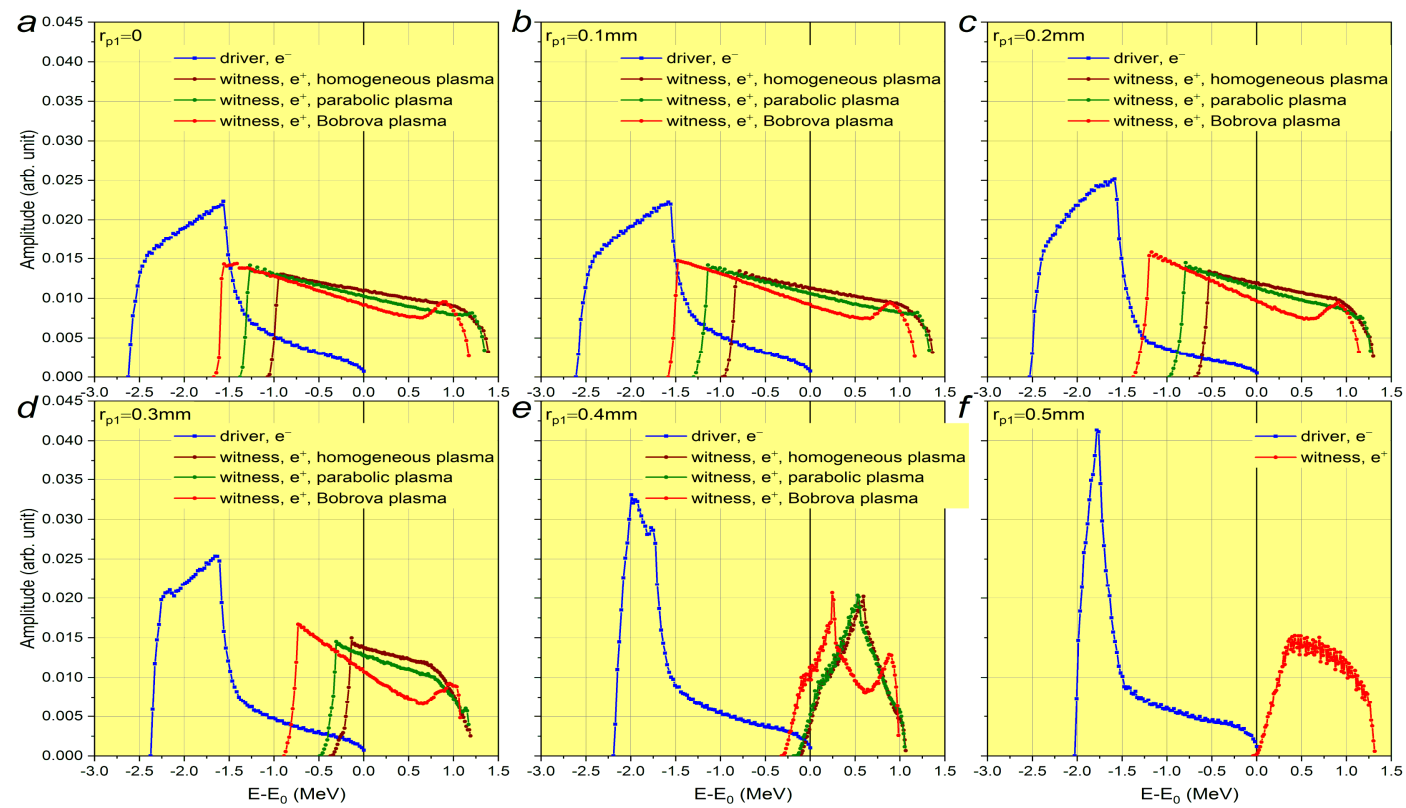

Fig. 9. Distribution functions of drive electron and test positron bunches on energy for homogeneous, parabolic plasma density dependence on radius received by N.A. Bobrova at different $r_{p 1}$ values:

$$
a-r_{p 1}=0 ; b-r_{p 1}=0.1 \mathrm{~mm} ; c-r_{p 1}=0.2 \mathrm{~mm} ; d-r_{p 1}=0.3 \mathrm{~mm} ; e-r_{p 1}=0.4 \mathrm{~mm} ; f-r_{p 1}=0.5 \mathrm{~mm}
$$

\section{CONCLUSIONS}

Results of numerical PIC-simulation research of wakefield excitation and self-consistent dynamics of the charged particles in the plasma-dielectric cylindrical slowing-down structure of terahertz frequency range for different models of the plasma received as a result of capillary discharge in waveguide are provided.

The carried-out numerical simulation has confirmed predictions of the analytical theory, having shown acceleration of test positron bunch with its simultaneous focusing.

It is shown that the vacuum channel in heterogeneous plasma column worsens focusing of the accelerated positron bunch, but promotes the increasing of it's acceleration.
The best acceleration happens in case of plasma absence, however at that there is no test positron bunch focusing.

\section{ACKNOWLEDGEMENTS}

The study is supported by the National Research Foundation of Ukraine under the program "Leading and Young Scientists Research Support" (project \# 2020.02/0299).

\section{REFERENCES}

1. W. Gai. Advanced accelerating structures and their interaction with electron beams // AIP Conf. Proc. 2009, v. 1086, p. 3-11. doi:10.1063/1.3080940.

2. Eric R. Colby. Present limits and future prospect for dielectric acceleration // Proc. of 35th Int. Conf. on high energy physics. Paris, France, 2010. 
3. W. Gai et al. Experimental demonstration of dielectric structure based two beam acceleration // AIP Conf. Proc. 2001, v. 569, p. 287-293. doi:10.1063/1.1384360.

4. M.C. Thompson et al. Breakdown limits on gigavolt-per-meter electron-beam-driven wakefields in dielectric structures // Phys. Rev. Lett. 2008, v. 100, p. 214801. doi:10.1103/PhysRevLett.100.214801.

5. W. Gai, J.G. Power, C. Jing. Short-pulse dielectric twobeam acceleration // J. Plasma Physics. Apr. 2012, v. 78, p. 339-345. doi:10.1017/S0022377812000037.

6. C. Li, W. Gai, C. Jing, et al. High gradient limits due to single bunch beam breakup in a collinear dielectric wakefield accelerator // Phys. Rev. ST Accel. Beams. 2014, v. 17, p. 1091 302-1 1091 302-7. doi:10.1103/PhysRevSTAB.17.091302.

7. R.R. Kniaziev, O.V. Manuilenko, P.I. Markov, T.C. Marshall, I.N. Onishchenko, G.V. Sotnikov. Focusing of electron and positron bunches in plasma-dielectric wakefield accelerators // Problems of Atomic Science and Technology. Series "Plasma Electronics and New Methods of Acceleration". 2013, № 4, p. 84-89.

8. G.V. Sotnikov, R.R. Kniaziev, O.V. Manuilenko, et al. Analytical and numerical studies of underdense and overdense regimes in plasma-dielectric wakefield accelerators // Nuclear Instruments and Methods in Physics Research Section A: Accelerators, Spectrometers, Detectors and Associated Equipment. 2014, v. 740, p 124-129. doi:10.1016/j.nima. 2013.10.087.
9. P.I. Markov, R.R. Kniaziev, I.N. Onishchenko, G.V. Sotnikov. Focusing of electron bunches in the plasma-dielectric rectangular slowing-down structure // Problems of Atomic Science and Technology. Series “Nuclear Physics Investigations”. 2016, № 3, p. 57-61.

10. R.R. Kniaziev, G.V. Sotnikov. Influence of emittance on transverse dynamics of accelerated bunches in the plasma-dielectric wakefield accelerator // Nuclear Instruments and Methods in Physics Research. Section A: Accelerators, Spectrometers, Detectors and Associated Equipment. 2016, v. 829, p. 121-124. doi:10.1016/j.nima.2016.03.097.

11. R.R. Knyazev, I.N. Onishchenko, and G.V. Sotnikov. Generation of wakefields in a dielectric structure filled with plasma // Technical Physics. 2016, v. 61, № 4, p. 511-516. doi:10.1134/S1063784216040113.

12. N.A. Bobrova, A.A. Esaulov, J.-I. Sakai, et al. Simulations of a hydrogen-filled capillary discharge waveguide // Phys. Rev. E. 2001, v. 65, p. 016407-1016407-11. doi:10.1103/PhysRevE.65.016407.

13. L.C. Steinhauer, W.D. Kimura. Quasistatic capillary discharge plasma model // Phys. Rev. ST Accel. Beams. 2006, v. 9, p. 081301-1-081301-10. doi:10.1103/PhysRevSTAB.9.081301.

14. G.V. Sotnikov, P.I. Markov, I.N. Onishchenko. Focusing of drive and test bunches in a dielectric waveguide filled with inhomogeneous plasma // Journal of Instrumentation. 2020, v. 15, p. C09001. doi:10.1088/1748-0221/15/09/C09001.

Article received 16.06.2021

\section{ФОКУСИРОВКА ПОЗИТРОННОГО СГУСТКА ПРИ ДВИЖЕНИИ В КИЛЬВАТЕРНОМ ПОЛЕ ЭЛЕКТРОННОГО СГУСТКА В ДИЭЛЕКТРИЧЕСКОМ ВОЛНОВОДЕ, ЗАПОЛНЕННОМ ПЛАЗМОЙ}

\section{Г.В. Сотников, Р.Р. Князев, П.И. Марков, И.Н. Онищенко}

Приведены результаты численного РІС-моделирования фокусировки тестового позитронного и драйверного электронного сгустков в диэлектрическом волноводе, заполненном радиально-неоднородной плазмой с вакуумным каналом. Кильватерное поле возбуждалось электронным сгустком в кварцевой диэлектрической трубке, вставленной в цилиндрический металлический волновод. Внутренняя область диэлектрической трубки была заполнена плазмой с различными поперечными профилями плотности, неоднородными по радиусу с вакуумным каналом вдоль оси волновода. Плазменная плотность для всех исследованных случаев была настолько низкой, что плазменная частота была меньше, чем частота основной диэлектрической моды. Результаты численного РІС-моделирования показали возможность одновременного ускорения и фокусировки тестового позитронного сгустка в кильватерном поле. Наилучшее ускорение происходит в случае отсутствия плазмы, однако при этом отсутствует фокусировка тестового сгустка позитронов.

\section{ФОКУСУВАННЯ ПОЗИТРОННОГО ЗГУСТКА ПРИ РУСІ В КІЛЬВАТЕРНОМУ ПОЛІ ЕЛЕКТРОННОГО ЗГУСТКА В ДІЕЛЕКТРИЧНОМУ ХВИЛЕВОДІ, ЗАПОВНЕНОМУ ПЛАЗМОЮ}

\section{Г.В. Сотніков, Р.Р. Князєв, П.І. Марков, І.М. Онищенко}

Наведено результати чисельного РІС-моделювання фокусування тестового позитронного й драйверного електронного згустків у діелектричному хвилеводі, заповненому радіально-неоднорідною плазмою з вакуумним каналом. Кільватерне поле збуджувалося електронним згустком у кварцовій діелектричній трубці, що вставлена в циліндричний металевий хвилевід. Внутрішня область діелектричної трубки була заповнена плазмою з різними поперечними профілями щільності неоднорідними по радіусу з вакуумним каналом уздовж осі хвилеводу. Плазмова щільність для всіх досліджених випадків була настільки низькою, що плазмова частота була менша, ніж частота основної діелектричної моди. Результати чисельного РІС-моделювання показали можливість одночасного прискорення й фокусування тестового позитронного згустка в кільватерному полі. Найкраще прискорення відбувається у випадку відсутності плазми, однак при цьому відсутнє й фокусування тестового згустка позитронів. 